\title{
Biological and ecological characterization of the catfish Cathorops melanopus off the west coast of Campeche, Mexico
}

\author{
Caracterización biológica y ecológica del bagre Cathorops melanopus \\ de la costa oeste de Campeche, México
}

\author{
LA Ayala-Pérez ${ }^{1,2}$, J Ramos-Miranda², D Flores-Hernández², BI Vega-Rodríguez¹, UC Moreno-Medina ${ }^{1}$ \\ ${ }^{1}$ Departamento El Hombre y su Ambiente, Universidad Autónoma Metropolitana Xochimilco, Calz. Del Hueso 1100 , Col. \\ Villaquietud, Coyoacán, 04960 México, DF.*E-mail: luayala13@yahoo.com.mx \\ ${ }^{2}$ Centro de Ecología, Pesquerías y Oceanografía del Golfo de México, Universidad Autónoma de Campeche, Av. Agustín \\ Melgar s/n entre Juan de la Barrera y calle 20, Col. Buenavista, CP 24030, Campeche, Campeche, México.
}

\begin{abstract}
Cathorops melanopus is the most abundant fish on the west coast of Campeche, Mexico. Its distribution is influenced by water temperature, salinity, and transparency, and it is frequently found in river outlets. To analyze the main biological and ecological patterns of this species, from February 2003 to February 2004 a total of 19,048 specimens were collected using a trawl net at 37 sampling stations along the west coast of Campeche. A subsample was formed of 14,446 randomly selected specimens, and each one was measured and weighed (length range $=35-302 \mathrm{~mm}$, mode $=90 \mathrm{~mm}$; weight range $=0.1-224 \mathrm{~g}$, mode $=6 \mathrm{~g})$. The highest mean abundance values were recorded in May $\left(1.24 \mathrm{ind} \mathrm{m}^{-2}, 15.31 \mathrm{~g} \mathrm{~m}^{-2}\right.$, and $\left.12.26 \mathrm{~g}^{-1}\right)$, and the lowest in April $\left(0.25\right.$ ind $\mathrm{m}^{-2}, 2.5 \mathrm{~g} \mathrm{~m}^{-2}$, and $9.9 \mathrm{~g}$ ind $\left.^{-1}\right)$. The parameters of the weight/length model were $a=1 \times 10^{-5}$ and $b=2.96$, with a correlation coefficient of 0.95 . The relative condition factor showed a major pulse in July $\left(2.1 \times 10^{-5}\right)$. The female:male ratio was 1:0.69. Of the 159 females collected, 111 had gonads at maturity stages II and III, and only one was in stage IV. The most common food item was unidentified organic matter, which represented $79 \%$ of the total stomach content weight and $92.1 \%$ of the encountered food types; the second most abundant food item was crustacean remains $(4.8 \%$ of the total weight and $10 \%$ of the encountered contents). Growth parameters were: $L_{\infty}=317.5 \mathrm{~mm}, K=0.45, C=0.7$, WP $=0.16$, and $t_{0}=7.5 \times 10^{-12}$. Total mortality was 1.22 , while natural mortality was 0.65 . Recruitment patterns showed a significant pulse between July and August, which together contributed $47.65 \%$ of the total number of specimens collected.
\end{abstract}

Key words: Campeche, catfish, Cathorops melanopus, growth, mortality, trophic spectrum.

\section{Resumen}

Cathorops melanopus es la especie de pez más abundante en la región occidental de la costa de Campeche. Su distribución está influenciada por la temperatura, la salinidad y la turbidez, mostrando preferencia por las desembocaduras de ríos. De febrero de 2003 a febrero de 2004 se recolectaron con una red de arrastre un total de 19,048 organismos en 37 estaciones ubicadas en la porción occidental de la costa de Campeche. De una submuestra, se midieron y pesaron individualmente 14,446 organismos. La longitud total de los organismos varió entre 35 y $302 \mathrm{~mm}$, con una moda de $90 \mathrm{~mm}$, y un intervalo de peso de 0.1 a $224 \mathrm{~g}$, con una moda de $6 \mathrm{~g}$. La mayor abundancia de organismos se registró en mayo, con valores de 1.24 ind $\mathrm{m}^{-2}, 15.31 \mathrm{~g} \mathrm{~m}^{-2}$ y $12.26 \mathrm{~g}$ ind $^{-1}$, y la menor en abril con 0.25 ind m-2, $2.5 \mathrm{~g} \mathrm{~m}^{-2}$ y $9.9 \mathrm{~g} \mathrm{ind}^{-1}$. El modelo peso/talla se integró con los parámetros $a=1 \times 10^{-5}, b=2.96$ con una correlación de 0.95 . El valor del factor de condición relativo presenta un pulso mayor en julio de $2.1 \times 10^{-5}$. La proporción de sexos hembras:machos fue de 1:0.69. La mayoría de las hembras (111) de un total de 159 se encontraron en las fases II y III y sólo una en fase IV. El grupo alimenticio que más se encontró fue material orgánico no identificado con $79 \%$ de peso y $92.1 \%$ de frecuencia, seguido por restos de crustáceos, con $4.8 \%$ de peso y $10 \%$ de frecuencia. Los parámetros de crecimiento encontrados fueron $L_{\infty}=317.5 \mathrm{~mm}, K=0.45, C=0.7, \mathrm{WP}=0.16$ y $t_{0}=-0.2163$. La mortalidad total fue de 1.22 y la natural de 0.65 . El reclutamiento se presenta con un pulso significativo entre julio y agosto con una aportación conjunta del $47.65 \%$.

Palabras clave: bagre, Campeche, Cathorops melanopus, crecimiento, espectro trófico, mortalidad.

\section{Introduction}

The coastal area between Tabasco and Campeche (Mexico) is an important shrimp fishing zone, particularly for the seabob shrimp (Xiphopenaeus kroyeri Heller 1862). This activity

\section{Introducción}

El litoral entre Tabasco y Campeche es una zona importante para la pesca de camarón, especialmente del camarón siete barbas (Xiphopenaeus kroyeri Heller 1862 ). En esta 
is associated with considerable bycatch, consisting of around 100 fish species of limited utilization. One of the most abundant and unexploited species found in the sea-bob bycatch is the catfish Cathorops melanopus Günther 1864. This species represents $42 \%$ of the total fish bycatch and constitutes a fundamental link in the process of energy transformation, conduction, exchange, and storage in the ecosystem. The catfish is known to inhabit diverse environments, including high salinity, sandy sediment, high water transparency, and seagrass habitats; however, it is most frequently caught in turbid water, nutrient-rich, low salinity, and clayey-silt sediment habitats, mainly in the southern and southwestern parts of Términos Lagoon, Campeche, areas highly influenced by river inputs (Yáñez-Arancibia et al. 1985).

Despite the ecological importance of C. melanopus, few studies have been conducted on its biology and ecology (LaraDomínguez et al. 1981, Yáñez-Arancibia and Lara-Domínguez 1988, Vega-Cendejas 1990, Galindo-Cortes 2002). These studies coincide in that C. melanopus has a high level of morphological, reproductive, feeding, and migratory adaptation, closely related to physico-environmental processes and habitat heterogeneity in lagoon-estuarine systems, which has resulted in large populations. This study therefore aimed to: (a) analyze the spatial and temporal variation in abundance; (b) determine the length-weight relationship; (c) analyze the population size structure; (d) analyze the temporal size frequency in order to generate growth, mortality, and recruitment models; (e) analyze the gonads to determine the gender and maturity phases and evaluate the sex ratio and reproductive season; and (f) analyze the stomach contents to determine food preferences of $C$. melanopus.

\section{Material and methods}

The study area $\left(18^{\circ} 15^{\prime}-18^{\circ} 45^{\prime} \mathrm{N}, 91^{\circ} 30^{\prime}-92^{\circ} 45^{\prime} \mathrm{W}\right.$; fig. 1) comprises the area of distribution of $X$. kroyeri (NúñezMárquez and Wakida 1999, Núñez-Márquez et al. 2000). A network of 37 sampling stations was established covering the area's diverse environments, considering aspects such as depth, river inputs, estuarine influence, and sediment type.

Fish samples were collected monthly from February 2003 to February 2004, using a trawl net (5 m long, $2.5 \mathrm{~m}$ opening, $1.9 \mathrm{~cm}$ mesh size) equipped with $0.4 \times 0.6 \mathrm{~m}$ doors, operated at a speed of 2 knots during $12 \mathrm{~min}$, covering an approximate area of $1800 \mathrm{~m}^{2}$. At each station, dissolved oxygen, $\mathrm{pH}$, salinity, and bottom and surface water temperature were measured with a Hydrolab H20 probe (Hach Co., USA). Depth and water transparency were also measured using a Secchi disk.

Captured organisms were identified based on identification keys (Fischer 1978, Castro-Aguirre 1999, Cervigón et al. 1992), and individually measured and weighed. Abundance was estimated in terms of biomass $\left(\mathrm{g} \mathrm{m}^{-2}\right)$, density (ind $\mathrm{m}^{-2}$ ), and mean weight $\left(\mathrm{g} \mathrm{ind}^{-1}\right)$, and analyzed on a spatial and temporal scale. The temporal analysis considered the three regional climatic seasons as proposed by Yáñez-Arancibia and actividad se observa una intensa captura de fauna de acompañamiento, la cual está integrada por cerca de 100 especies de peces con un aprovechamiento muy limitado. Entre las especies más abundantes de la fauna de acompañamiento del camarón siete barbas que no se aprovechan se encuentra el bagre Cathorops melanopus Günther 1864, que representa $42 \%$ del total de peces capturados incidentalmente. El bagre $C$. melanopus constituye un eslabón fundamental en el proceso de transformación, conducción, intercambio y almacenamiento de energía en el ecosistema. Esta especie ha sido reportada como habitante de diversos ambientes, desde hábitats con elevada salinidad, sedimentos arenosos y gran transparencia, con praderas de pastos marinos, hasta hábitats de aguas turbias, ricas en nutrientes, salinidad baja y de sedimentos limo-arcillosos, donde se le captura con más frecuencia, principalmente hacia la parte sur y suroccidental de la Laguna de Términos, en Campeche; es decir, en las áreas influenciadas por la descarga de ríos (Yáñez-Arancibia et al. 1985).

A pesar de la importancia ecológica de C. melanopus, sólo se han realizado unos cuantos trabajos específicos sobre su biología y ecología (Lara-Domínguez et al. 1981, YáñezArancibia y Lara-Domínguez 1988, Vega-Cendejas 1990, Galindo-Cortes 2002). Estos trabajos coinciden en que $C$. melanopus tiene un alto nivel de adaptación morfológica, reproductiva, alimenticia y migratoria, íntimamente ligado a los procesos físico-ambientales y a la heterogeneidad del hábitat en los sistemas estuarino-lagunares, lo que ha permitido su gran éxito poblacional. Por ello, los objetivos de este estudio fueron: (a) analizar la distribución espacial y temporal de la abundancia; (b) determinar la relación talla-peso; (c) analizar la estructura por tallas de la población; (d) analizar temporalmente la frecuencia de tallas para generar los modelos de crecimiento, mortalidad y reclutamiento; (e) analizar gónadas para determinar sexo y fase de madurez para determinar la proporción de sexos y época de reproducción; y (f) analizar contenidos estomacales para determinar las preferencias alimentarias de C. melanopus.

\section{Materiales y métodos}

El área de estudio se localiza entre $18^{\circ} 15^{\prime}-18^{\circ} 45^{\prime} \mathrm{N} \mathrm{y}$ $91^{\circ} 30^{\prime}-92^{\circ} 45^{\prime} \mathrm{W}$ (fig. 1), que es la zona de distribución del camarón siete barbas según lo reportado por Núñez-Márquez y Wakida (1999) y Núñez-Márquez et al. (2000). Se estableció una red de 37 sitios de muestreo que cubren los diversos ambientes identificados en la zona, considerando aspectos como profundidad, descarga de ríos, influencia estuarina y tipo de sedimento.

Las recolectas se realizaron con una frecuencia mensual, de febrero de 2003 a febrero de 2004. La captura se efectuó con una red de arrastre de $5 \mathrm{~m}$ de largo y $2.5 \mathrm{~m}$ de abertura de trabajo, con una luz de malla de $1.9 \mathrm{~cm}$, equipada con tablas de $0.4 \times 0.6 \mathrm{~m}$, y operada a una velocidad de 2 nudos durante 12 min, cubriendo un área aproximada de $1800 \mathrm{~m}^{2}$. En cada estación se registraron los parámetros ambientales de oxígeno 


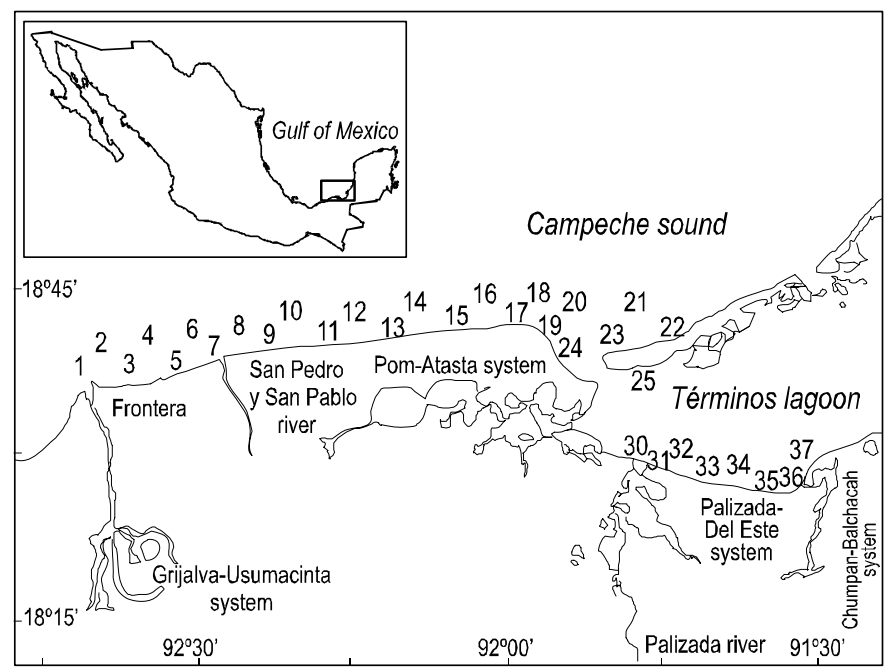

Figure 1. Sampling stations in the study area.

Figura 1. Estaciones de muestreo en el área de estudio.

Day (1982): dry (February to May), rainy (June to September), and winter when northerlies (Nortes) occur (October to January). Distribution models were generated for the spatial representation by the Kriging interpolation technique using Surfer software (Smith et al. 1995).

The length-weight relationship was calculated as a power function where $a$ is the origin ordinate and slope $b$ is the allometric coefficient (Pauly 1983). The Fulton relative condition factor (K1) was determined using the following equation:

$$
\mathrm{K} 1=\mathrm{TW} / \mathrm{TL}^{b}
$$

where TW is the total weight and TL the total length (Ricker 1958).

Growth, mortality, and recruitment models were generated based on size frequency analyses using specialized computer software. To determine the size frequency distribution, kernel density estimators (KDE) were applied (Rosenblatt 1956):

$$
f_{x}=1 / h n \sum_{i=1}^{n} K\left(x-X_{i} / h\right)
$$

where $f_{x}$ is the density estimate of variable $x, n$ is the number of observations, $h$ is the band amplitude or smoothing parameter, and $K\left(x-X_{i} / h\right)$ is the kernel function (smooth and symmetric probability density, integrating the unit). Assuming that the samples present a normal behaviour, the Gaussian kernel was used:

$$
(1 / \sqrt{2 \pi}) * e^{(-1 / 2) z^{2}}
$$

where $z=x-X_{i} / h$ (Salgado-Ugarte et al. 1995). disuelto, $\mathrm{pH}$, salinidad, y temperatura, a dos niveles de profundidad (fondo y superficie), con ayuda de un medidor Hydrolab H20 (Hach Co., EUA). Adicionalmente, se registró la profundidad y la transparencia con un disco de Secchi.

Los organismos capturados se identificaron con ayuda de claves de identificación (Fischer 1978, Castro-Aguirre 1999, Cervigón et al. 1992) y fueron medidos y pesados individualmente. La abundancia fue estimada en términos de biomasa ( $\mathrm{g}$ $\mathrm{m}^{-2}$ ), densidad (ind $\mathrm{m}^{-2}$ ) y peso medio $\left(\mathrm{g} \mathrm{ind}^{-1}\right)$ y se analizó tanto en escala temporal como espacial. El análisis temporal consideró lo propuesto por Yáñez-Arancibia y Day (1982) sobre las épocas climáticas de la región: de secas (febrero a mayo), de lluvias (junio a septiembre) y de Nortes (octubre a enero). Para su representación espacial se generaron modelos de distribución a través de la técnica de interpolación Kriging con ayuda del programa Surfer (Smith et al. 1995).

La relación talla-peso se calculó como una función potencial donde $a$ es la ordenada al origen y la pendiente $b$ es el coeficiente de alometría (Pauly 1983). El factor de condición relativo de Fulton (K1) se determinó mediante la expresión:

$$
\mathrm{K} 1=\mathrm{PT} / \mathrm{LT}^{b}
$$

donde PT es el peso total y LT la longitud total (Ricker 1958).

Los modelos de crecimiento, mortalidad y reclutamiento se generaron a partir del análisis de frecuencia de tallas utilizando programas especializados de cómputo. Para la determinación de la distribución de frecuencia por tallas se aplicaron los estimadores de densidad por kernel (EDK) (Rosenblatt 1956):

$$
f_{x}=1 / h n \sum_{i=1}^{n} K\left(x-X_{i} / h\right)
$$

donde $f_{x}$ es la estimación de densidad de la variable $x, n$ es el número de observaciones, $h$ es la amplitud de banda o parámetro de suavización, y $K\left(x-X_{i} / h\right)$ es la función kernel (densidad de probabilidad suave, simétrica y que integra a la unidad). Se supuso que las muestras presentan un comportamiento normal por lo que se utilizó el kernel Gaussiano:

$$
(1 / \sqrt{2 \pi}) * e^{(-1 / 2) z^{2}}
$$

donde $z=x-X_{i} / h$ (Salgado-Ugarte et al. 1995).

En todos los casos se utilizó el ancho de banda óptimo de Silverman (1986):

$$
\hat{h}=0.79(\mathrm{RIC}) n-1 / 5
$$

donde $\hat{h}$ es la amplitud de banda estimada, $n$ es el número de observaciones, y RIC es el recorrido intercuartílico. Los pasos antes mencionados se realizaron de acuerdo con las rutinas descritas por Salgado-Ugarte (2002), e incluidas en el software 
In all cases the optimal bandwidth proposed by Silverman (1986) was used:

$$
\hat{h}=0.79(\mathrm{IQR}) n-1 / 5
$$

where $\hat{h}$ is the estimated band amplitude, $n$ is the number of observations, and IQR is the interquartilic range. The above steps were performed according to the routines described by Salgado-Ugarte (2002), and included in the Stata software (StataCorp 1999). After constructing the size frequency table, the values were entered into the FiSAT program (FAOICLARM Stock Assessment Tools) (Gayanillo et al. 1996). Using the ELEFAN I routine, we estimated the values of the $L_{\infty}$ and $K$ parameters of the von Bertalanffy growth model; this software describes seasonal growth:

$$
L_{t}=L_{\infty}\left[1-e^{\left(-K\left(t-t_{0}\right)-(C K / 2 \pi) \sin \left(2 \pi\left(t-t_{s}\right)\right)\right)}\right]
$$

where $L_{t}$ is the length at age $t, L_{\infty}$ is the infinite length, $K$ is the growth constant, $C$ is the amplitude of the growth oscillations relative to time, $t_{0}$ is the age at zero length, and $t_{\mathrm{s}}=\mathrm{WP}-0.5$ (WP = winter point, the period of the year when growth is slowest; Sparre and Venema 1995).

The value of $t_{0}$ was calculated using the von Bertalanffy inverse equation:

$$
t_{0}=t+1 / K \times \ln \left(L_{\infty}-L_{t} / L_{\infty}\right)
$$

Total mortality and the recruitment pattern were determined using FiSAT. Total mortality was quantified using the capture curve linearized by the following negative exponential model:

$$
N_{t}=N_{0} e^{-Z t}
$$

where $N_{t}$ is the number of organisms at age $t$ and $Z$ is the total mortality. Linearizing this expression we get:

$$
\ln N_{t}=\ln N_{0}-Z t
$$

where the value of $Z$ (total mortality) is the slope and $N_{0}$ the value of the origin ordinate.

Natural mortality was estimated by the algorithm proposed by Pauly (1980):

$\log M=-0.0066-0.279 \log L_{\infty}+0.6543 \log K+0.4634 \log T$

where $M$ is the natural mortality, $L_{\infty}$ is the infinite length, $K$ is the growth constant, and $T$ is the temperature $\left({ }^{\circ} \mathrm{C}\right)$.

The recruitment pattern was obtained by back-projecting a set of length-frequency samples within a time axis to infer the
Stata (StataCorp 1999). Una vez construida la tabla de frecuencia por talla se incorporaron los valores al programa FiSAT (FAO-ICLARM Stock Assessment Tools) (Gayanillo et al. 1996). A través de la rutina ELEFAN I se estimaron los valores de los parámetros $L_{\infty}$ y $K$ del modelo de crecimiento de von Bertalanffy; este software describe el crecimiento a partir de la versión estacionalizada:

$$
L_{t}=L_{\infty}\left\lceil 1-e^{\left(-K\left(t-t_{0}\right)-(C K / 2 \pi) \sin \left(2 \pi\left(t-t_{s}\right)\right)\right)}\right\rceil
$$

donde $L_{t}$ es la longitud a la edad $t, L_{\infty}$ es la longitud infinita, $K$ es la constante de crecimiento, $C$ es la amplitud de las oscilaciones de crecimiento con respecto al tiempo, $t_{0}$ es la edad a la cual la longitud es cero, y $t_{\mathrm{s}}=\mathrm{WP}-0.5$ (winter point) es la parte del año en que la tasa de crecimiento es mínima (Sparre y Venema 1995).

El valor de $t_{0}$ se calculó a partir de la ecuación inversa de von Bertalanffy:

$$
t_{0}=t+1 / K \times \ln \left(L_{\infty}-L_{t} / L_{\infty}\right)
$$

La mortalidad total y el patrón de reclutamiento se determinaron con ayuda del programa FiSAT. La mortalidad total se cuantificó mediante la curva de captura linealizada con el siguiente modelo exponencial negativo:

$$
N_{t}=N_{0} e^{-Z t}
$$

donde $N_{t}$ es el número de organismos a la edad $t$ y $Z$ es la mortalidad total. Al linealizar esta expresión se obtiene:

$$
\ln N_{t}=\ln N_{0}-Z t
$$

donde el valor de $Z$ (mortalidad total) es la pendiente y $N_{0}$ el valor de la ordenada al origen.

La mortalidad natural se estimó mediante el algoritmo propuesto por Pauly (1980):

$\log M=-0.0066-0.279 \log L_{\infty}+0.6543 \log K+0.4634 \log T$

donde $M$ es la mortalidad natural, $L_{\infty}$ es la longitud infinita, $K$ es la constante de crecimiento, y $T$ es la temperatura $\left({ }^{\circ} \mathrm{C}\right)$.

El patrón de reclutamiento se obtuvo al proyectar un juego de muestras longitud-frecuencia hacia atrás en un eje de tiempo para inferir el número de pulsos de reclutamiento en el periodo de tiempo analizado. Por otra parte, para los análisis de sexo, madurez gonádica y contenido estomacal se tomó una submuestra seleccionada de manera aleatoria estratificada por tallas. Las determinaciones de sexo y madurez gonádica se realizaron con base en los criterios morfológicos propuestos por Nikolsky (1963), mientras que los contenidos estomacales se evaluaron de acuerdo los criterios propuestos por Laevastu 
number of recruitment pulses in the time period analyzed. For the gender, gonadal maturity, and stomach content analyses, a size-stratified subsample was randomly selected. Gender and gonadal maturity were determined following the morphological criteria proposed by Nikolsky (1963), while stomach contents were evaluated according to Laevastu (1971) and Prejs and Colomine (1981). To establish the food preference of C. melanopus, gravimetric, numeric, and frequency techniques were employed. The index of relative importance (IRI, Pinkas et al. 1971) was also calculated:

$$
\mathrm{IRI}=F(N+G)
$$

where $F$ is the frequency percentage, $N$ is the numeric percentage, and $G$ is the gravimetric percentage.

\section{Results}

A total of 19,048 specimens of C. melanopus were caught and the total weight was $253.57 \mathrm{~kg}$. Of these, 14,446 individuals were randomly selected for our evaluations, and each one was measured and weighed. They had a combined weight of $199.98 \mathrm{~kg}$ and the total length of the organisms ranged from 35 to $302 \mathrm{~mm}$, with a mode at $94.2 \mathrm{~mm}$.

Cathorops melanopus showed a wide distribution in the study area, though the highest abundances were observed at the stations closest to the outlets of the Grijalva-Usumacinta, Palizada, and Chumpam rivers, during the months corresponding to the rainy season. The highest abundance concentration areas occurred at the outlets of the Grijalva-Usumacinta and Palizada-Del Este river systems (fig. 2). The highest abundance values were recorded in October and December, but the largest sized organisms were observed in June, August, and September (fig. 3).

The length-weight relationship of C. melanopus showed a nearly isometric growth with a value of 2.96 and a mean condition factor of $1 \times 10^{-5}$ (fig. 4). The monthly behaviour of the mean Fulton condition factor showed two main pulses of better population conditions, the strongest one between May and July and the other in December (fig. 5).

The size structure of the C. melanopus population was described considering the class range estimated based on Silverman's optimal bandwidth calculated using the KDE, which was $6.28 \mathrm{~mm}$. Figure 6 shows a discontinuous version of the KDE per size, where a length mode of $94.2 \mathrm{~mm}$ is noticed.

The monthly size frequency converted to density table was entered into the FiSAT program to search for the parameters of the von Bertalanffy growth model. The best fit was obtained with the following set of values: $L_{\infty}=317.5 \mathrm{~mm}, K$ $=0.45, C=0.7, \mathrm{WP}=0.16, \mathrm{SS}=8, \mathrm{SL}=37.7$, and $t_{0}$ $=-0.2163$, and a $R n=0.157$. Total mortality $(Z)$ estimated by the size-converted catch curve was 1.22 , with a determination coefficient $\left(R^{2}\right)$ of 0.96 (fig. 7). Natural mortality estimated by the Pauly algorithm was 0.65 , with a mean
(1971) y Prejs y Colomine (1981). Para establecer la preferencia alimenticia de la especie se utilizaron las técnicas gravimétrica, numérica y de frecuencia; además se calculó el índice de importancia relativa (IRI) (Pinkas et al. 1971) que se expresa como IRI $=F(N+G)$, donde $F$ es el porcentaje de frecuencia, $N$ es el porcentaje numérico y $G$ es el porcentaje gravimétrico.

\section{Resultados}

Se capturaron en total 19,048 organismos de C. melanopus, con un peso total de $253.57 \mathrm{~kg}$, de los cuales 14,446 fueron medidos y pesados de manera individual con un peso conjunto de $199.98 \mathrm{~kg}$ y son la base del análisis en este trabajo. Las tallas de los organismos oscilaron entre 35 y $302 \mathrm{~mm}$ de longitud total, con una moda en la marca de clase $94.2 \mathrm{~mm}$.

Cathorops melanopus mostró una amplia distribución en el área de estudio; sin embargo, los valores de abundancia son mayores en las estaciones cercanas a las desembocaduras de los sistemas fluviales Grijalva-Usumacinta, Palizada y Chumpam, y en los meses que corresponden a la época de lluvias. Las áreas de mayor concentración de abundancia se observaron en las desembocaduras de los sistemas GrijalvaUsumacinta y Palizada-Del Este (fig. 2). En octubre y diciembre se registraron los mayores valores de abundancia, pero los organismos de mayor talla se registraron en junio, agosto y septiembre (fig. 3).

La relación peso-talla en C. melanopus mostró un crecimiento cerca del isométrico con un valor de 2.96 y con un factor de condición medio de $1 \times 10^{-5}$ (fig. 4). El comportamiento del promedio mensual del factor de condición de Fulton mostró dos pulsos principales de mejor condición de la población, el primero entre mayo y julio, y el segundo, menor, en diciembre (fig. 5).

La estructura por tallas de la población de C. melanopus se describe considerando el intervalo de clase estimado a partir del ancho de banda óptima de Silverman calculado mediante los EDK que fue de $6.28 \mathrm{~mm}$. En la figura 6 se muestra una versión discontinua de los EDK por talla, donde se identifica una talla modal de $94.2 \mathrm{~mm}$.

La tabla de frecuencia de tallas convertida a densidad por mes se incorporó al programa FiSAT para la búsqueda de los parámetros del modelo de crecimiento de von Bertalanffy. El mejor ajuste se encontró con $L_{\infty}=317.5 \mathrm{~mm}, K=0.45, C=0.7$, $\mathrm{WP}=0.16, \mathrm{SS}=8, \mathrm{SL}=37.7$ y $t_{0}=-0.2163$, y un $R n=0.157$. La mortalidad total estimada $(Z)$ mediante la curva de captura convertida a tallas es de 1.22 con un coeficiente de determinación $R^{2}=0.96$ (fig. 7). La mortalidad natural estimada mediante el algoritmo de Pauly es de 0.65 con una temperatura media de $27.1^{\circ} \mathrm{C}$. Finalmente en el modelo de reclutamiento se destaca un pulso entre julio y agosto con un porcentaje conjunto del $47.65 \%$ (fig. $7 \mathrm{c}$ ).

De 279 organismos que fueron seleccionados en forma aleatoria estratificada por talla, y que corresponden a los meses de junio, agosto, octubre, noviembre y diciembre de 2003 y febrero de 2004, sólo en 159 casos fue posible reconocer 

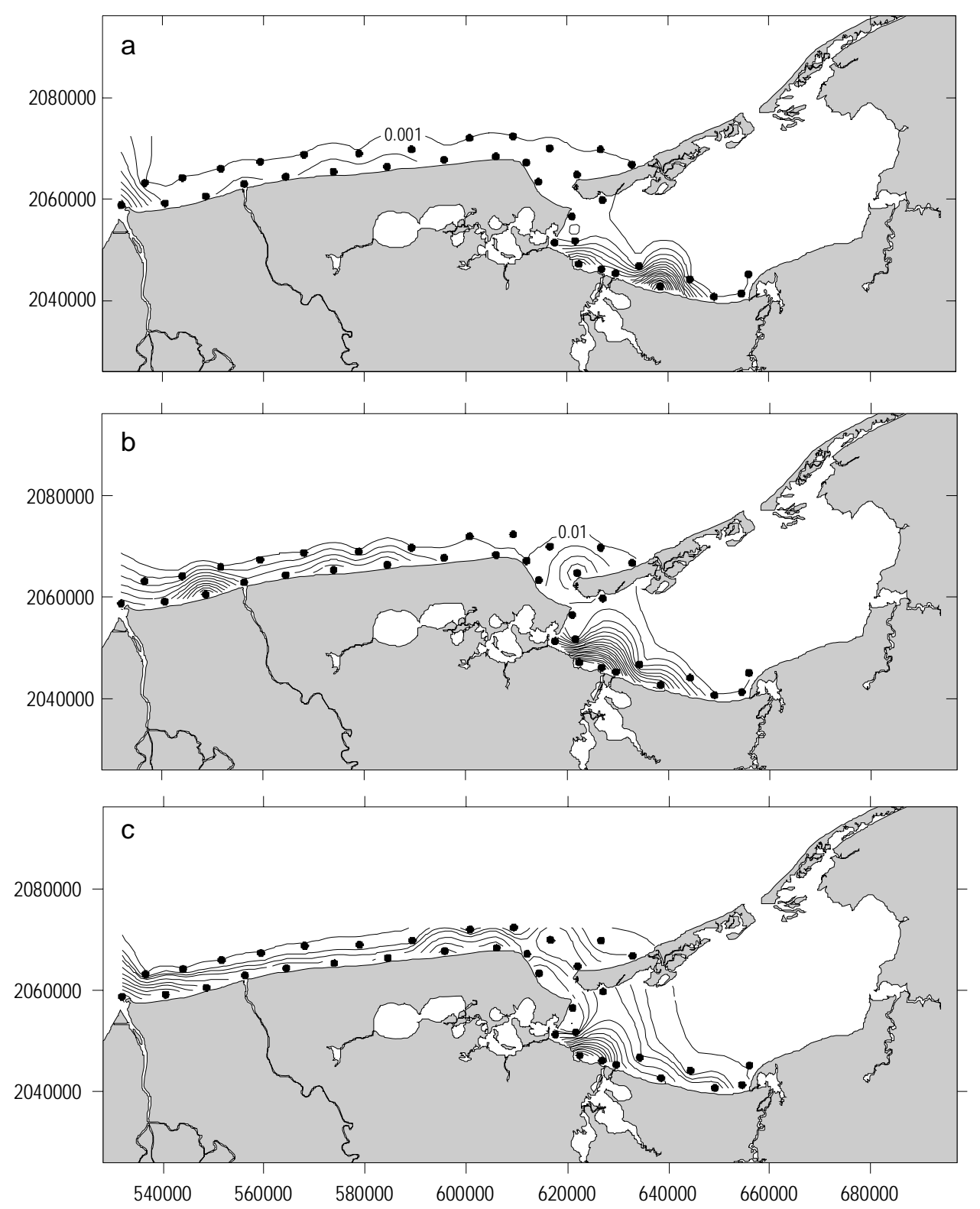

Figure 2. Spatial model of the density distribution by regional climatic season: (a) dry season, (b) rainy season, and (c) winter storm (Nortes) season. Figura 2. Modelo espacial de la distribución de densidad por la época climática regional: (a) secas, (b) lluvias y (c) nortes.

temperature of $27.1^{\circ} \mathrm{C}$. Finally, the recruitment model revealed a pulse between July and August, with a combined percentage of $47.65 \%$ (fig. $7 \mathrm{c}$ ).

Of 279 organisms that were randomly selected by size, ranging from 43 to $300 \mathrm{~mm}$ TL and corresponding to June, August, October, November and December 2003, and February 2004 , only in 159 cases was it possible to clearly determine the gender: 111 females and 48 males. The proportion of sexes per gonadal stage showed a prevalence of females especially in stages II and VI (fig. 8). On the other hand, eggs were observed in the snout, and a similar proportion of both sexes performed oral incubation.

The stomach content analysis revealed 41 full, 45 nearly full, 139 nearly empty, and 45 empty stomachs. When present, claramente el sexo. Las tallas de los organismos seleccionados oscilaron entre 43 y $300 \mathrm{~mm} \mathrm{LT}$, y se encontraron 111 hembras y 48 machos. La proporción de sexos por fase gonádica mostró una prevalencia de hembras sobre todo en fases II y VI (fig. 8). Por otro lado, se observó la presencia de huevos en el hocico resultando que en proporción similar ambos sexos realizan la incubación oral.

En cuanto al análisis de estómagos se encontró que 41 estaban llenos, 45 casi llenos, 139 casi vacíos y 45 vacíos. De los que tenían algún contenido, éste se encontraba digerido en 201 casos y medio digerido en 22 casos. Numéricamente el grupo trófico mejor representado fue el de los anfípodos con 45.3\%, seguido por los nemátodos con $17 \%$ y los anélidos con $10.7 \%$; gravimétricamente el alimento mejor representado fueron los 

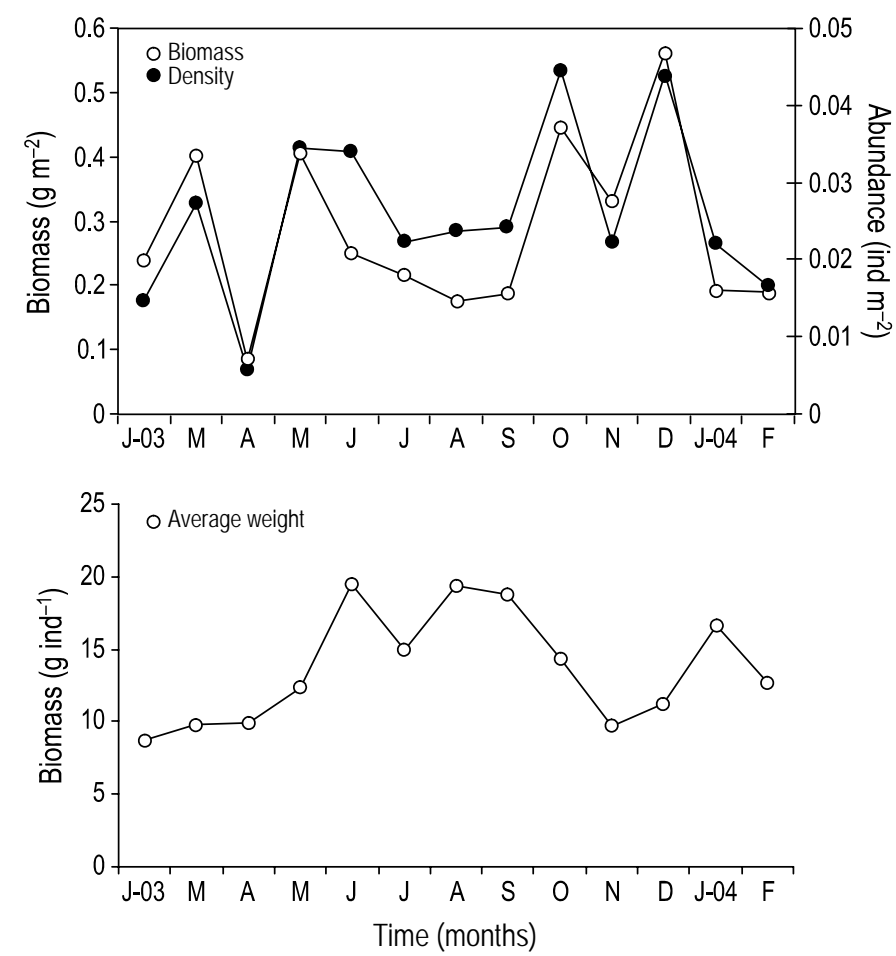

Figure 3. Temporal pattern of biomass, density, and average weight of Cathorops melanopus.

Figura 3. Patrón temporal de biomasa, densidad y peso medio de Cathorops melanopus.

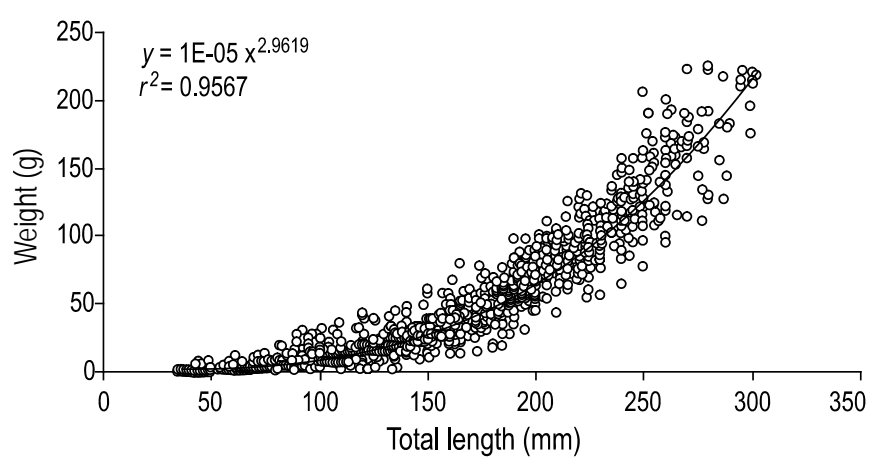

Figure 4. Weight-length relationship of Cathorops melanopus.

Figura 4. Relación peso-longitud de Cathorops melanopus.

the content was digested in 201 cases and partially digested in 22 cases. Numerically, amphipods were the best represented trophic group (45.3\%), followed by nematodes (17\%), and annelids (10.7\%). Gravimetrically, crustaceans were the best represented food item $(7.82 \%)$, followed by crustacean remains $(4.9 \%)$, and fish remains $(2.9 \%)$. The food frequency technique showed that crustacean remains were the most common $(10.1 \%)$, followed by unidentified organic matter (UOM, $10 \%)$, and amphipods (7.5\%). The index of relative importance (Pinkas et al. 1975) revealed that the preferential food item was UOM, followed by amphipods and crustacean remains (fig. 9).

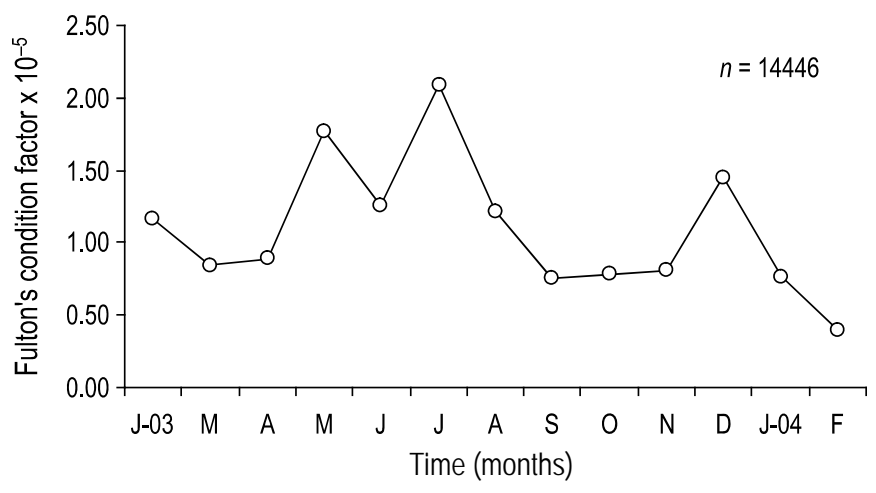

Figure 5. Temporal pattern of the condition factor of Cathorops melanopus. Figura 5. Patrón temporal del factor de condición de Cathorops melanopus.

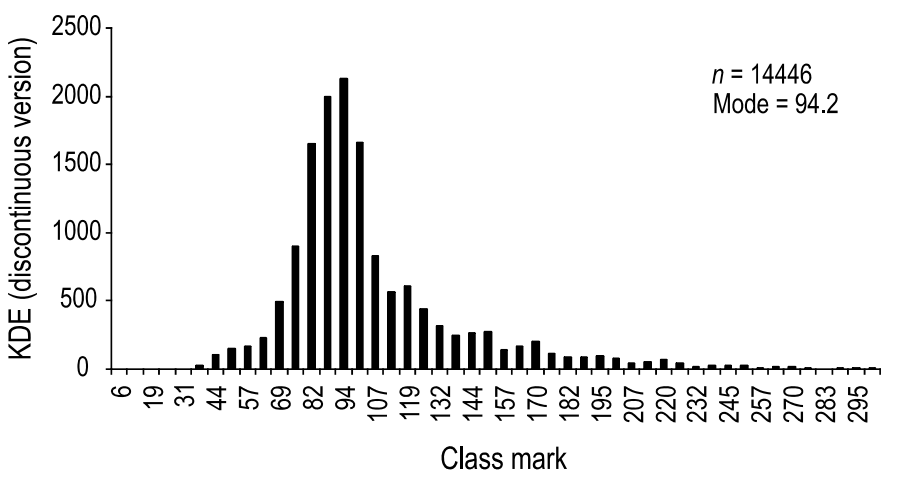

Figure 6. Length structure of Cathorops melanopus (KDE = kernel density estimators).

Figura 6. Estructura de longitud de Cathorops melanopus.

crustáceos con $7.82 \%$, seguidos por restos de crustáceos con $4.9 \%$ y restos de peces con $2.9 \%$, y por frecuencia de aparición se observó una mayor representación de restos de crustáceos con $10.1 \%$, materia orgánica no identificada (MONI) con un $10 \%$, y anfípodos con un $7.5 \%$. El índice de importancia relativa de Pinkas et al. (1975) destaca como alimento preferente la MONI, seguida por los anfípodos y los restos de crustáceos (fig. 9).

\section{Discusión}

Cathorops melanopus presentó una distribución fuertemente asociada con las desembocaduras de los ríos, en particular en los sistemas Palizada-Del Este y Grijalva-Usumacinta durante el periodo de muestreo; sin embargo, muestra una amplia distribución y tolerancia a variaciones de salinidad $(0.2$ $-40)$ y temperatura $\left(20-34^{\circ} \mathrm{C}\right)$. De acuerdo con los modelos de distribución espacial de la abundancia, su hábitat se amplía durante las épocas de nortes y secas, y se reduce durante la época de lluvias. Este comportamiento se explica por el efecto retrasado del incremento en el volumen de la descarga de los ríos, dada la amplitud de la planicie costera. El máximo volumen de descarga se registra entre octubre y diciembre y el mínimo entre mayo y junio. 

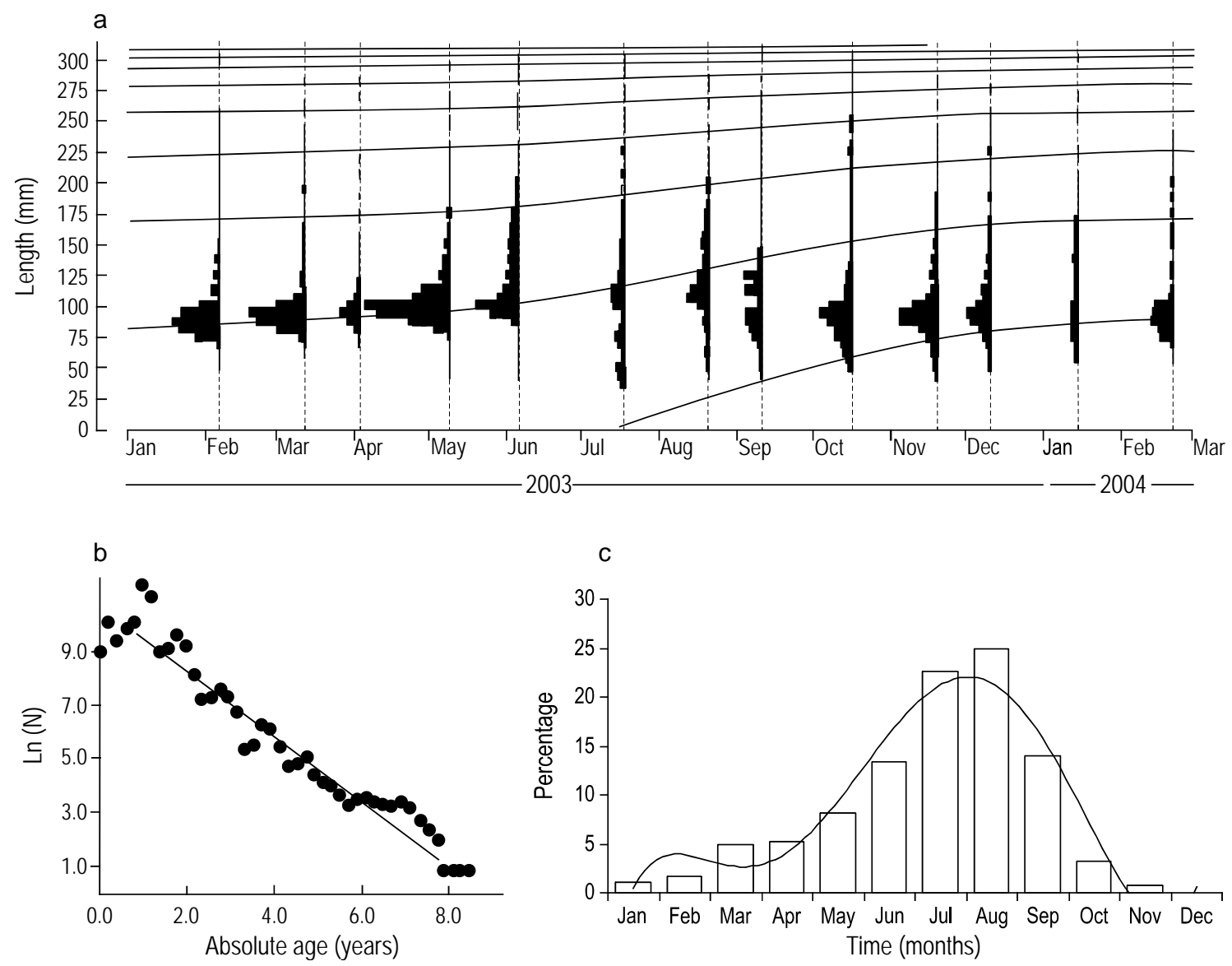

Figure 7. Growth lines adjusted to length frequency data, capture curve, and recruitment model of Cathorops melanopus.

Figura 7. Líneas de crecimiento ajustadas a los datos de la frecuencia de longitud, la curva de captura y el modelo de reclutamiento de Cathorops melanopus.

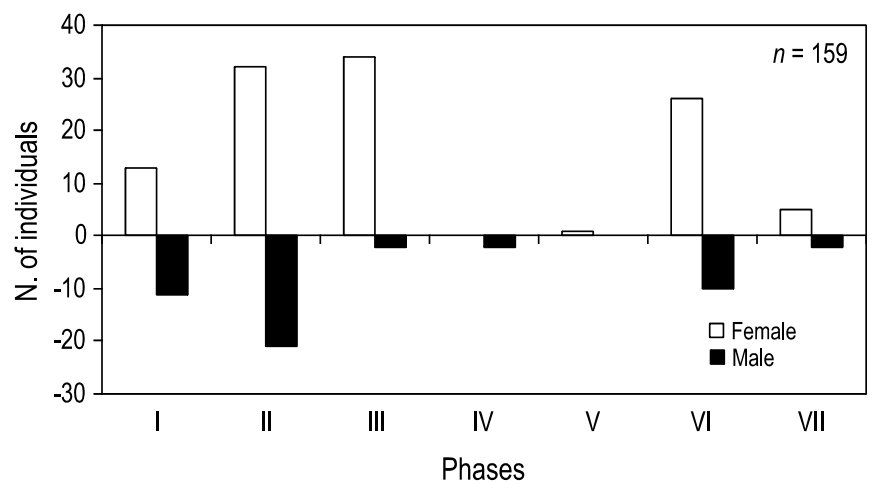

Figure 8. Gender proportion by gonadal maturity phase of Cathorops melanopus.

Figura 8. Proporción de sexos por la fase de madurez gonádica de Cathorops melanopus.

\section{Discussion}

The distribution of C. melanopus during the study period was strongly associated with river outlets, especially those of the Palizada-Del Este and Grijalva-Usumacinta systems. Nevertheless, this species is widely distributed and tolerates wide
Cathorops melanopus se ha reportado como la especie más abundante de la comunidad de peces de la Laguna de Términos, y se caracteriza por su preferencia por zonas de alta turbidez y baja salinidad (Lara-Domínguez et al. 1981, YáñezArancibia y Lara-Domínguez 1988). La presencia de C. melanopus en praderas de Thalassia testudinum donde prevalecen condiciones de alta salinidad y transparencia se ha reportado como cíclica (Yáñez-Arancibia y Lara-Domínguez 1983, Álvarez-Guillén et al. 1985, Vargas-Maldonado y YáñezArancibia 1987), lo que permite argumentar la expansión temporal de su hábitat y su capacidad de movimiento y tolerancia a las variaciones ambientales.

La abundancia relativa de esta especie en la región se ha incrementado sensiblemente en años recientes. Mientras que Ayala-Pérez et al. (2003) reportaron una proporción de $26.5 \%$ de la captura total de peces en un estudio realizado en la Laguna de Términos, en el presente estudio se ha encontrado una proporción del $42 \%$. En cuanto a la biomasa, los intervalos de variación encontrados en ambos trabajos también se incrementaron de $0.43-6.54 \mathrm{~g} \mathrm{~m}^{-2}$ a $2.53-15.32 \mathrm{~g} \mathrm{~m}^{-2}$, respectivamente.

El bagre C. melanopus mostró un crecimiento alométrico negativo (2.961), esto es, que el incremento de su talla 
variations in salinity $(0.2-40)$ and temperature $\left(20-34^{\circ} \mathrm{C}\right)$. According to the spatial distribution models of the abundance, its habitat extends during the dry and winter (Nortes) seasons and reduces during the rainy season. This pattern is explained by the delayed effect of the increase in river discharges, given the extent of the coastal plain. Maximum river discharge occurs between October and December, and minimum in May and June.

It has been reported that $C$. melanopus is the most abundant fish species in Términos Lagoon and that it shows a preference for high turbidity and low salinity areas (Lara-Domínguez et al. 1981, Yáñez-Arancibia and Lara-Domínguez 1988). It has also been reported to occur cyclically in Thalassia testudinum meadows, where high water transparency and salinity conditions prevail (Yáñez-Arancibia and Lara-Domínguez 1983, Álvarez-Guillén et al. 1985, Vargas-Maldonado and YáñezArancibia 1987). This indicates a temporal expansion of its habitat and ability to move and tolerate environmental variations.

The relative abundance of C. melanopus in the region has increased in recent years. Ayala-Pérez et al. (2003) reported that it comprised $26.5 \%$ of the total fish landings of Términos Lagoon, whereas in this study we found a proportion of $42 \%$. Regarding the biomass variation ranges, these also increased from $0.43-6.54$ to $2.53-15.32 \mathrm{~g} \mathrm{~m}^{-2}$, respectively.

Cathorops melanopus showed a negative allometric growth (2.961), that is, its increase in length was proportionally greater than its increase in weight. The mean condition factor was 0.00001 , with a determination factor of 0.956 . González and Santos (2000) obtained values of $a=0.0089$ and $b=2.95$ in a study conducted on this species in Términos Lagoon between 1997 and 1999. This indicates a better condition of the organisms in the inner part of the lagoon, which is understandable given the high availability of food and wide variety of refuge habitats within it.

The monthly mean condition factor reflects two important moments for the population during the year, one between May and July and another, although not as major, in December. This behaviour is related to the preparations for spawning because, given the catfish's food preferences, it can be assumed that food is not limited and that the species takes advantage of the conditions during both the maximum and minimum river discharges.

Small-sized organisms (TL $<100 \mathrm{~mm}$ ) maintain high densities in the outlets of the lagoon/river systems, while largesized organisms are more frequently found in areas farther away from these abundance nuclei. It can thus be assumed that tolerance to changes in salinity increases with size. The population consisted of organisms ranging in size from 35 to $302 \mathrm{~mm}$ TL, with a mode at $94.2 \mathrm{~mm}$. On the one hand this size structure reflects the selectivity of the fishing gear, and on the other an early reproductive strategy. The size at first maturity was $144.5 \mathrm{~mm}$ TL for females and $162.1 \mathrm{~mm}$ TL for males. This concurs with Lara-Domínguez et al. (1981), who reported a size at first maturity of 160-165 mm TL.
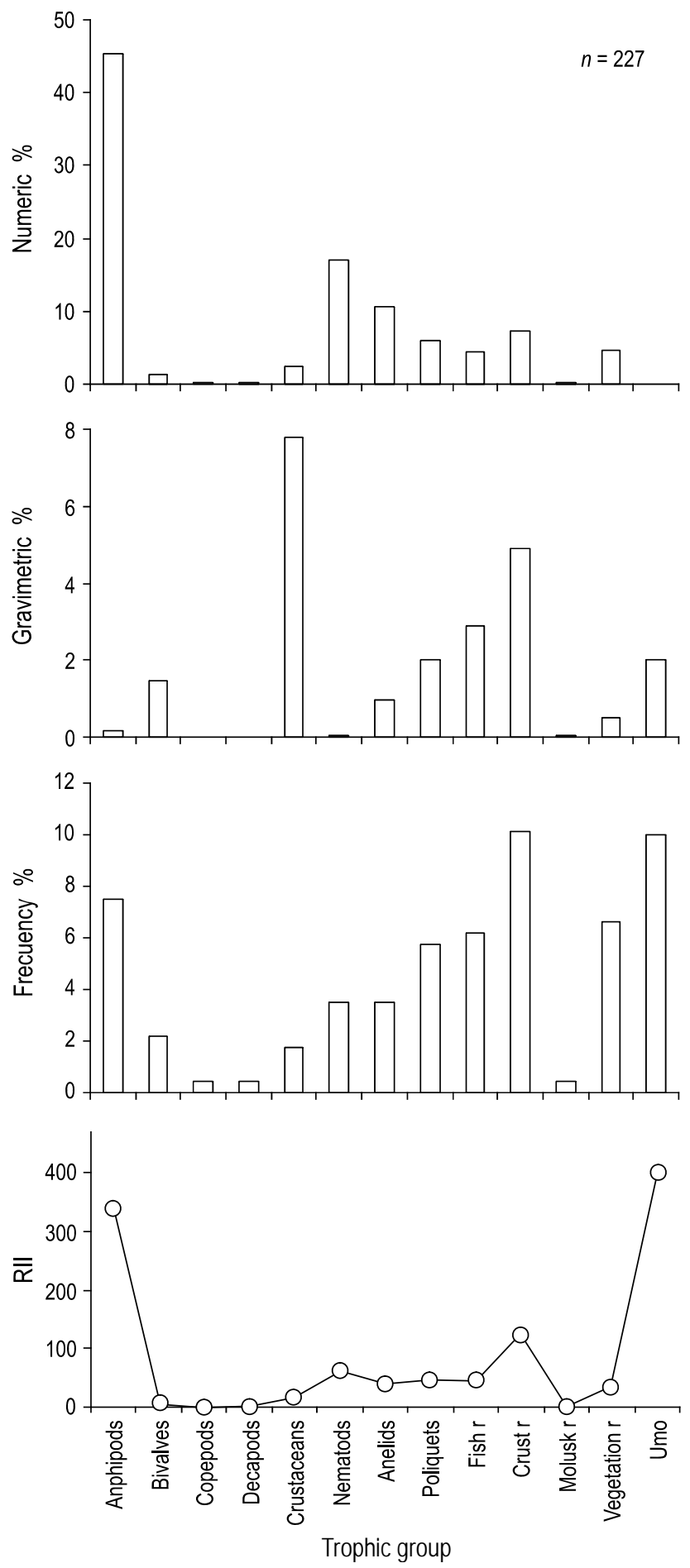

Figure 9. Trophic spectrum of Cathorops melanopus.

Figura 9. Espectro trófico de Cathorops melanopus.

es mayor en proporción a su peso. En el ajuste del modelo potencial, el factor de condición medio es de 0.00001 con un factor de determinación de 0.956. González y Santos (2000) reportaron valores de $a=0.0089$ y $b=2.95$ en un estudio realizado para esta especie en la Laguna de Términos entre 1997 y 1999. Lo anterior señala una mejor condición de los 
The highest concentration of phase I and II organisms occurred in the outlets of the lagoon/river systems (PalizadaDel Este and Grijalva-Usumacinta). This concurs with that reported by Yáñez-Arancibia and Lara-Domínguez (1988), and indicates that the species spawns and incubates under low salinity, low water transparency, and high temperature conditions.

According to Lara-Domínguez et al. (1981), Vidal (1985), and Yáñez-Arancibia and Lara-Domínguez (1988), C. melanopus shows continuous reproductive activity, with a massive reproductive event occurring during the rainy season. This condition is comparable with that found by Rojas et al. (1994) for the catfish Cathorops spixii, Hexanematichthys guatemalensis, $H$. seemanni, $H$. osculus, $H$. dowii, and Rhamdia guatemalensis. In a comparative study of the Tampamachoco (Veracruz) and Pom-Atasta (Campeche) catfish populations, Galindo-Cortes (2002) proposed considering the following values as reasonable for the growth parameters of C. melanopus: $L_{\infty}$ ranging from 300 to $370 \mathrm{~mm}$ and $K$ from 0.3 to 0.5 per year. These values are comparable with those obtained in the growth model developed here. It is also worth noting that a maximum size of $230 \mathrm{~mm}$ TL is reported in the FishBase database (Froese and Pauly 2004) and that Vidal (1985) recorded a maximum size of $401.3 \mathrm{~mm}$ for specimens from the Tonalá River (Veracruz). For Términos Lagoon, González and Santos (2000) reported growth values of $L_{\infty}=$ $400 \mathrm{~mm}$ and $K=0.44$ per year for $C$. melanopus; though the $L_{\infty}$ value is higher than that obtained in this study $\left(L_{\infty}=317.5\right.$ $\mathrm{mm})$, the growth constant is practically the same $(K=0.45$ per year), indicating a similar growth in both studies.

The value of the amplitude constant $(C=0.7)$ reflects an important variation in growth due to environmental variabilities, in particular the change in salinity and temperature associated with the increase in river discharges and the seasons. In the case of the winter point (WP $=0.16$ ), February is considered the coldest month (mean water temperature of $23^{\circ} \mathrm{C}$ ); the winter point reflects the time of year when growth is slowest, and it can be affected by temperature as well as other factors such as feeding and salinity variations.

González and Santos (2000) estimated a total mortality of 3.0 and a natural mortality of 0.93 per year using the same methods as in the present study. These data are proportionally higher than ours, leading to speculations about the reproductive success of this species especially in the inner part of Términos Lagoon, where there is an evident increase in the levels of abundance. The reproductive strategies, displacement of competitive species, increased levels of river-transported organic matter, and even the effects of protecting the natural area can be used to argument the increase in abundance and decrease in the mortality indices of this species. Moreover, González and Santos (2000) reported a two-period recruitment pattern: the first and most important (72\%) from March to June, and the second (27\%) from August to October; however, since the value of $t_{0}$ was not given, a comparative discussion is not possible. organismos al interior de la laguna. Esta situación es comprensible dada la gran disponibilidad de alimento y la gran variedad de hábitat de refugio y protección dentro de la laguna.

El factor de condición medio mensual refleja dos momentos importantes para la población durante el año, una entre mayo y julio y otra, aunque comparativamente menor, en diciembre. Este comportamiento está relacionado con los momentos de preparación para el desove ya que, dadas las preferencias alimentarias de la especie, podemos suponer que el alimento no es restrictivo y C. melanopus aprovecha tanto las condiciones de máxima descarga de los ríos como las condiciones de mínimo aporto fluvial.

Los organismos de tallas pequeñas (LT $<100 \mathrm{~mm}$ ) mantienen las altas densidades en las desembocaduras de los sistemas fluvio-lagunares, y son organismos de tallas grandes los que con más frecuencia se registran en las zonas más alejadas a estos núcleos de abundancia, lo que hace suponer que con la talla se incrementa la tolerancia a los cambios de salinidad. La población está conformada por organismos con tallas entre 35 y $302 \mathrm{~mm}$ de longitud total, con una moda en la marca de clase $94.2 \mathrm{~mm}$. Esta estructura por tallas refleja por una parte la selectividad del arte de pesca, pero también corresponde con una estrategia de reproducción temprana. La talla de primera madurez registrada es de $144.5 \mathrm{~mm}$ LT para hembras y 162.1 $\mathrm{mm}$ LT para machos, lo cual coincide con lo reportado por Lara-Domínguez et al. (1981), quienes encontraron una talla de primera madurez entre 160 y $165 \mathrm{~mm}$ LT.

La mayor concentración de organismos en fases I y II se localiza principalmente en las desembocaduras de los sistemas fluvio-lagunares (Palizada-Del Este y Grijalva-Usumacinta), lo que coincide con lo reportado por Yáñez-Arancibia y LaraDomínguez (1988), destacando que la especie desova e incuba en condiciones de baja salinidad, poca transparencia y alta temperatura.

De acuerdo con Lara-Domínguez et al. (1981), Vidal (1985) y Yáñez-Arancibia y Lara-Domínguez (1988), C. melanopus muestra un comportamiento de reproducción continua; sin embargo, también coinciden en señalar que en la época de lluvias se presenta un evento masivo de reproducción. Esta condición es comparable con lo reportado por Rojas et al. (1994) para los bagres Cathorops spixii, Hexanematichthys guatemalensis, $H$. seemanni, $H$. osculus, $H$. dowii y Rhamdia guatemalensis. Galindo-Cortes (2002), en un estudio comparativo entre las poblaciones de bagre de Tampamachoco (Veracruz) y Pom-Atasta (Campeche), propuso que se pueden considerar como rangos razonables de parámetros de crecimiento para $C$. melanopus, $L_{\infty}$ entre 300 y $370 \mathrm{~mm}$ y $K$ entre 0.3 y 0.5 por año. Estos valores son comparables con lo registrado en el modelo de crecimiento aquí desarrollado. También cabe mencionar que la base de datos FishBase (Froese y Pauly 2004) reporta una talla máxima de $230 \mathrm{~mm}$ LT y adicionalmente Vidal (1985) reporta una talla máxima de $401.3 \mathrm{~mm}$ para especímenes del Río Tonalá (Veracruz). Para la Laguna de Términos, González y Santos (2000) señalan los siguientes valores de parámetros de crecimiento para la especie: $L_{\infty}=400$ 
Regarding the feeding habits if C. melanopus in Términos Lagoon, Lara-Domínguez et al. (1981) and Lara-Domínguez (1986) reported UOM, tanaidaceans, and copepods as the preferential food items, and pelecypods, crustacean remains, and nematodes as the secondary food items, while for lagoon/ river systems they reported UOM, plant remains, and copepods as preferential food, and nematodes, insect larvae, and tanaidaceans as secondary food items. Kobelkowsky and Castillo-Rivera (1995) observed that copepods, tanaidaceans, and amphipods represented $34.75 \%$, detritus $35.92 \%$, fish $6.82 \%$, plants $2.32 \%$, and decapods $2.0 \%$ of the relative importance of the diet of C. melanopus at Pueblo Viejo Lagoon (Veracruz). Vega-Cendejas (1990) found that in the port of Celestún (Yucatan), crustaceans constituted $41 \%$, fish 25.2\%, polychaetes $12.9 \%$, vegetal matter $6.3 \%$, detritus $5.7 \%$, molluscs $3.3 \%$, sand $2.5 \%$, and poriferans $1.3 \%$ of the total diet of C. melanopus. At this same site, Vega-Cendejas et al. (1994) observed that polychaetes constituted $35.9 \%$, microcrustaceans $21.1 \%$, detritus $14.1 \%$, fish $15 \%$, decapods $7.5 \%$, molluscs $3.5 \%$, plant remains $0.6 \%$, and nematodes $1.9 \%$ of the total weight of the food.

Our results suggest that $C$. melanopus shows a preference for copepods, fish, crustaceans, and polychaetes, and is therefore considered to be a second order consumer. These findings are in agreement with Amezcua-Linares and Yáñez-Arancibia (1980), Vargas-Maldonado et al. (1981), Yáñez-Arancibia and Lara-Domínguez (1983), Vargas-Maldonado and YáñezArancibia (1987), and Álvarez-Guillén et al. (1985). This species plays a fundamental role in energy transformation, conduction, exchange, and storage in the ecosystem, and monitoring its population size is considered necessary since it can represent a natural response to modifications in the patterns of organic matter transported by rivers and, in turn, provoke negative effects on the diversity of the fish community. Because $C$. melanopus is such an abundant and tolerant species, it could function as a biological indicator of drastic changes in the community

\section{Acknowledgements}

This study received financial support from the project "Evaluación de los dos principales recursos pesqueros de importancia comercial: camarón (siete barbas, camarón blanco) y pulpo en el litoral de Campeche" (FOMIX CAMP 2005 C01 040)". We thank O Chávez-Rivero, H ÁlvarezGuillén, and F Gómez-Criollo for their valuable assistance in the field and laboratory sampling processes.

English translation by Christine Harris.

\section{References}

Álvarez-Guillén H, Yáñez-Arancibia A, Lara-Domínguez AL. 1985. Ecología de la boca del Carmen, Laguna de Términos: El hábitat y estructura de las comunidades de peces. An. Inst. Cienc. Mar Limnol. 12:107-144. mm, $K=0.44$ por año; aunque el valor de $L_{\infty}$ es mayor que el obtenido en el presente estudio $\left(L_{\infty}=317.5 \mathrm{~mm}\right)$ la constante de crecimiento es prácticamente la misma ( $K=0.45$ por año), señalando un crecimiento similar en ambos estudios.

El valor de la constante de amplitud $(C=0.7)$ refleja una importante oscilación del crecimiento debida a la variabilidad ambiental, en particular los cambios en salinidad y temperatura condicionados por el incremento en el volumen de descarga de los ríos y las épocas climáticas. Para el caso del punto de invierno ( $\mathrm{WP}=0.16$ ) se ha considerado que el mes más frío es febrero $\left(23^{\circ} \mathrm{C}\right.$ temperatura media del agua); el WP refleja el momento del año en el que el crecimiento es menor, el cual puede estar influenciado además de la temperatura por otros factores como la alimentación y las variaciones en la salinidad.

González y Santos (2000) estimaron una mortalidad total de 3.0 y una mortalidad natural de 0.93 por año utilizando los mismos métodos que en este estudio. Estos datos son proporcionalmente más altos que los encontrados en el presente estudio, lo cual da pie para reflexionar sobre el éxito reproductivo de la especie particularmente al interior de la Laguna de Términos donde es evidente la tendencia de incremento en los niveles de abundancia. Las estrategias de reproducción, el desplazamiento de especies competidoras, el incremento en los niveles de materia orgánica transportada por los ríos e incluso los efectos de la protección del área natural constituyen temas de discusión para argumentar el incremento en la abundancia y la disminución de los índices de mortalidad de esta especie. Adicionalmente, González y Santos (2000) reportan un patrón de reclutamiento en dos periodos, el primero y más importante (72\%) de marzo a junio y el segundo (27\%) de agosto a octubre; sin embargo, no se reporta el valor de $t_{0}$ por lo que no es posible una discusión comparativa.

En cuanto a los hábitos alimentarios de C. melanopus en la Laguna de Términos, Lara-Domínguez et al. (1981) y LaraDomínguez (1986) coinciden en reportar como alimento preferente a la MONI, tanaidáceos y copépodos, y como alimento secundario a los pelecípodos, restos de crustáceos y nemátodos; mientras que en los sistemas fluvio-lagunares encontraron como alimento principal la MONI, restos vegetales y copépodos, y como secundario a los nematodos, larvas de insectos y tanaidáceos. Kobelkowsky y Castillo-Rivera (1995), en la Laguna de Pueblo Viejo (Veracruz), observaron que los copépodos y los tanaidáceos y anfípodos representaron el $34.75 \%$, el detritus $35.92 \%$, los peces $6.82 \%$, las plantas $2.32 \%$ y los decápodos el $2.0 \%$ de importancia relativa en la dieta de C. melanopus. Vega-Cendejas (1990) reportó que, en el puerto de Celestún (Yucatán), los crustáceos constituyen el 41\%, los peces el $25.2 \%$, poliquetos $12.9 \%$, materia vegetal $6.3 \%$, detritus $5.7 \%$, moluscos $3.3 \%$, arena $2.5 \%$ y poríferos $1.3 \%$, del total de la dieta de este pez. También en este mismo lugar, Vega-Cendejas et al. (1994) observaron que los poliquetos constituyen $35.9 \%$, los microcrustáceos $21.1 \%$, el detritus $14.1 \%$, los peces $15 \%$, los decápodos $7.5 \%$, los moluscos $3.5 \%$, restos vegetales $0.6 \%$ y los nematodos $1.9 \%$ del peso total del alimento. 
Amezcua-Linares F, Yáñez-Arancibia A. 1980. Ecología de los sistemas fluvio-lagunares asociados a la Laguna de Términos. El hábitat y estructura de las comunidades de peces. An. Inst. Cienc. Mar Limnol. 7: 68-118.

Ayala-Pérez LA, Ramos-Miranda J, Flores-Hernández D. 2003. La comunidad de peces en la Laguna de Términos: Estructura actual comparada. Rev. Biol. Trop. 51(3-4): 738-794.

Castro-Aguirre JL. 1999. Ictiofauna Estuarino-lagunar y Vicaria de México. Limusa, 705 pp.

Cervigón F, Cipriani R, Fischer W, Garibaldi L, Hendrickx M, Lemus AJ, Márquez R, Poutiers JM, Robaina G, Rodríguez B. 1992. Guía de campo de las especies comerciales marinas de aguas salobres de la costa septentrional del sur de América. FAO, Rome, 513 pp.

Fischer W. 1978. FAO Species identification sheets for fishery purposes. Western Central Atlantic (Fishing Area 31). FAO, Rome.

Froese R, Pauly D. 2004. FishBase. www.fishbase.org.

Galindo-Cortes G. 2002. Aplicación de los estimadores de densidad por kernel en el estudio del crecimiento del bagre estuarino Cathorops melanopus para dos lagunas del Golfo de México. Informe de Servicio Social, Universidad Autónoma Metropolitana, Unidad Xochimilco, 129 pp.

Gayanillo Jr FC, Sparre P, Pauly D. 1996. The FAO-ICLARM Stock Assessment Tools (FiSAT) User's Guide. FAO Computarized Information Series (Fisheries), Rome, $126 \mathrm{pp}$.

González RME, Santos J. (2000). Fichas técnicas de peces importantes en la Laguna de Términos, Campeche. Jaina 11(2):15.

Kobelkowsky A, Castillo-Rivera M. 1995. Sistema digestivo y alimentación de los bagres (Pisces: Ariidae) del Golfo de México. Hidrobiológica 5: 95-103.

Laevastu T. 1971. Manual de Métodos de Biología Pesquera. FAO. Acribia, Spain, 243 pp.

Lara-Domínguez AL. 1986. Biología y ecología comparada de los bagres marinos de la Laguna de Términos, Campeche, sur del Golfo de México (Pisces: Ariidae). M.Sc. thesis, Instituto de Ciencias del Mar y Limnología, Universidad Nacional Autónoma de México, $200 \mathrm{pp}$.

Lara-Domínguez AL, Yáñez-Arancibia A, Amezcua-Linares F. 1981. Biología y ecología del bagre Arius melanopus Gunther (Pisces: Ariidae). An. Inst. Cienc. Mar Limnol. 8(1): 267-304.

Nikolsky GV. 1963. The Ecology of Fishes. Academic Press, New York, $352 \mathrm{pp}$.

Núñez-Márquez G, Wakida AT. 1999. Evaluación del efecto de la veda de 1999 sobre la población y la pesca de camarón blanco en Campeche y Tabasco (primera parte: mayo a agosto). Rep. Téc. CRIP, Instituto Nacional de Pesca, México, 22 pp.

Núñez-Márquez G, Wakida AT, Guzmán V, Marín JM, Zamudio I, Avalos JC, Gutiérrez M. 2000. Seguimiento del camarón siete barbas durante la época de veda. El Timón. Secretaria de Pesca del Gobierno del Estado de Campeche 2(6): 2-4.

Pauly D. 1980. On the interrelationships between natural mortality, growth parameters and mean environmental temperature in 175 fish stock. J. Cons. CIEM 39(3): 175-192.

Pauly D. 1983. Algunos métodos simples para la evaluación de recursos pesqueros tropicales. Documento Técnico de Pesca 234, FAO, Rome, 49 pp.

Pinkas L, Oliphant S, Iverson IL. 1971. Food habits of albacore, blue fin tuna and bonito in California waters. Tech. Rep. 152. Calif. Dept. Fish and Game. Fish. Bull. 105 pp.

Prejs A, Colomine G. 1981. Métodos para el estudio de los alimentos y las relaciones tróficas de los peces. Universidad Central de Venezuela, Caracas, y Universidad de Varsovia, Polonia, 129 pp.

Ricker W. 1958. Handbook of computations for biological statistics of fish population. Bull. Fish. Res. Bd. Canada 119, 300 pp.
Los resultados de este estudio sugieren que C. melanopus tiene una preferencia por los copépodos, peces, crustáceos y poliquetos, por lo que se considera un consumidor de segundo orden coincidiendo con los trabajos de Amezcua-Linares y Yáñez-Arancibia (1980), Vargas-Maldonado et al. (1981), Yáñez-Arancibia y Lara-Domínguez (1983), VargasMaldonado y Yáñez-Arancibia (1987) y Álvarez-Guillén et al. (1985). El valor ecológico de esta especie como transformador y vehículo de energía es fundamental para el funcionamiento del ecosistema; sin embargo, el monitoreo de su tamaño poblacional se plantea como una necesidad ya que puede representar la respuesta natural a modificaciones en los patrones de carga de materia orgánica aportada por los ríos y a su vez provocar efectos negativos en la diversidad de la comunidad de peces. En este sentido esta especie pudiera funcionar como un indicador biológico ya que aunque es una especie abundante muy tolerante, es precisamente esta condición la que pudiera marcar un cambio drástico en la comunidad.

\section{Agradecimientos}

Este trabajo fue realizado con fondos obtenidos a través del proyecto "Evaluación de los dos principales recursos pesqueros de importancia comercial: camarón (siete barbas, camarón blanco) y pulpo en el litoral de Campeche" (FOMIX CAMP 2005 C01 040)". La participación de O Chávez-Rivero, H Álvarez-Guillén y F Gómez-Criollo en los trabajos de campo y en el procesamiento de muestras en laboratorio fue muy activa y valiosa.

Rojas JR, Castro M, Pizarro JF. 1994. Época de desove, fecundidad y morfología en cinco especies ícticas (Pisces: Ariidae) de manglar en Costa Rica. Rev. Biol. Trop. 42: 751-754.

Rosenblatt M. 1956. Remarks on some nonparametric estimates of a density function. Ann. Math. Stat. 27: 832-837.

Salgado-Ugarte IH, Shimizu M, Taniuchi T. 1995. ASH, WARPing, and kernel density estimation for univariate data. Stata Tech. Bull. 26: $23-31$

Salgado-Ugarte IH. 2002. Suavización no paramétrica para análisis de datos. Facultad de Estudios Superiores Zaragoza, UNAM, México, 139 pp.

Silverman BW. 1986. Density Estimation for Statistics and Data Analysis. Chapman \& Hall, London, 175 pp.

Smith D, Wall W, Chen Z, Barnes R, Simons B. 1995. Surface Mapping System. Surfer (win 32) Ver. 6.0.1. Golden Software, Colorado.

Sparre P, Venema SC. 1995. Introducción a la evaluación de recursos pesqueros tropicales. Parte I. Manual FAO. Documento Técnico de Pesca No. 306/1, 490 pp.

StataCorp. 1999. Stata satistical software: Release 6.0. Stata Corporation. Collage Station Texas.

Vargas-Maldonado I, Yáñez-Arancibia A. 1987. Estructura de las comunidades de peces en sistemas de pastos marinos (Thalassia testudinum) de la Laguna de Términos, Campeche, México. An. Inst. Cienc. Mar Limnol. 14: 181-196.

Vargas-Maldonado I, Yáñez-Arancibia A. Amezcua-Linares F. 1981. Ecología y estructura de las comunidades de peces en áreas de Rizhophora mangle y Thalassia testudinum de la Isla del Carmen, 
Laguna de Términos, sur del Golfo de México. An. Inst. Cienc. Mar Limnol. 8(1): 241-266.

Vega-Cendejas E. 1990. Interacción trófica entre los bagres Cathorops melanopus (Agassiz 1829) y Arius felis (Linnaeus 1766), en las costas de Celestún, Yucatán, México. An. Inst. Cienc. Mar Limnol. 17(2): 271-285.

Vega-Cendejas ME, Hernández M, Arreguín-Sánchez F. 1994. Trophic interrelations in a beach seine fishery from the northwestern coast of the Yucatan peninsula, Mexico. J. Fish Biol. 44: 647-659.

Vidal QJ. 1985. Crecimiento y aspectos poblacionales del bagre Arius melanopus (Gunter 1864) del Río Tonalá, Veracruz. B.Sc. thesis, Universidad Nacional Autónoma de México, 35 pp.

Yáñez-Arancibia A, Day Jr. JW. 1982. Ecological characterization of Terminos Lagoon, a tropical lagoon-estuarine system in the southern Gulf of Mexico. In: Lasserre P, Postma H (eds.), Coastal Lagoons. Oceanol. Acta Spec. Publ. 5(4): 417-429.
Yáñez-Arancibia A, Lara-Domínguez AL. 1983. Dinámica ambiental de la boca del Estero Pargo y estructura de sus comunidades de peces en cambios estacionales y ciclos de 24 horas (Laguna de Términos, sur del Golfo de México). An. Inst. Cienc. Mar Limnol. 10(1): 85-116.

Yáñez-Arancibia A, Lara-Domínguez AL. 1988. Ecology of three sea catfishes (Ariidae) in a coastal ecosystem: Southern Gulf of Mexico. Mar. Ecol. Prog. Ser. 49: 215-230.

Yáñez-Arancibia A, Lara-Domínguez AL, Aguirre-León A, DíazRuiz S, Amezcua-Linares F, Flores Hernández D, Chavance P. 1985. Ecología de poblaciones de peces dominantes en estuarios tropicales: Factores ambientales que regulan las estrategias biológicas y la producción. Chap. 15. In: Yáñez-Arancibia A (ed.), Fish Community Ecology in Estuaries and Coastal Lagoons: Towards an Ecosystem integration. Universidad Nacional Autónoma de México, pp. 311-366.

Recibido en abril de 2008; aceptado en octubre de 2008. 